\title{
THE CONTRIBUTION OF ECCLESIAL COMMUNITIES TO THE DEVELOPMENT OF COMMUNITY WORK: WORKING RELIGIOUS CAPITAL
}

\author{
Valters Dolacis, Dace Dolace \\ Latvian Christian Academy
}

\begin{abstract}
The goal of the article is to describe the contribution of ecclesial or Church communities to the development of community work and the ways people get involved in community activities, seeing ecclesial communities as form of religious capital in society for regenerating the society and individuals. In the richness of community activities of Christian Church that are socially or caritatively-oriented, it is possible to find resources, with which the Christian Church can reach the people in need and fulfil its mission. Thus, the context of the article is the practical concept of Caritative Social Work being practiced in practical domains of modern social protection system. One of the factors, chosen for studying in this article, will be religious capital with its inner constituting conditions in order there could take place their activation in community environment. The task here is to explore specific social and religious factors and principles of action that would provide more full understanding about the effectiveness of functioning of local religious communities and their influence on community development. The article will end by case study analysis of two Christian ecclesial communities and deriving working principles, finding out which elements and principles of ecclesial community can constitute the effective community of social rehabilitation.

KEY WORDS: community work, ecclesial communities, religious capital.
\end{abstract}

\begin{abstract}
Anotacija
Straipsnyje siekiama atskleisti Bažnyčios bendruomenių indèlį, skatinant jų narių aktyvumą ir įtraukiant žmones ị bendruomenès veiklą. Bažnyčios bendruomenès vertinamos kaip visuomenès religinio veikimo forma, skatinant individus veikti. Krikščionių Bažnyčios bendruomeninei socialinei ar karitatyvinei veiklai ieškoma išteklių, kurie per Krikščionių Bažnyčią pasiektų žmones, kuriems reikia pagalbos, taip vykdoma misija. Šio straipsnio kontekstas - praktinè karitatyvinio socialinio darbo koncepcija, praktikuojama šiuolaikinëje socialinės apsaugos sistemoje. Vienas analizei pasirinktų koncepcijos veiksnių - religinis kapitalas, leidžiantis sudaryti sąlygas aktyvinti bendruomeninę aplinką. Siekiama atskleisti konkrečius socialinius ir religinius veiksnius bei principus, kurie leidžia geriau suprasti vietinių religinių bendruomenių veiklos veiksmingumą ir jų įtaką bendruomenès vystymuisi. Straipsnyje pristatoma dviejų krikščioniškų bažnytinių bendruomenių atvejų analizè ir tų bendruomenių darbo principai, veikiantys bendruomenès socialinès reabilitacijos procesus.

PAGRINDINIAI ŽODŽIAI: bendruomenès darbas, bažnytinès bendruomenès, religinis kapitalas.
\end{abstract}

DOI: http://dx.doi.org/10.15181/tbb.v78i1.1755

\section{Introduction}

The target group of community-based work are people who found themselves in hardships of life and have lost their will, powers of life, their resilience and socialization skills in order to regain a balance both in personal life and in relations- 
hips with environment as well as to develop a new quality of life. In the model of community relationships, people involved are not in passive, awaiting dependence from existing power structures and services, but they turn into ones who take upon responsibility for what is happening - people gather around the problem they cannot solve each one separately, the problem that directly influences their life. Such kind of organization in community work substantially influences the quality of achieving commonly set goals.

The goal of the article is to describe the contribution of ecclesial ${ }^{1}$ or Church communities to the development of community work and the ways people get involved in community activities, seeing ecclesial communities as form of religious capital in society for regenerating the society and individuals. In the richness of community activities of Christian Church that are socially or caritatively-oriented, it is possible to find resources, with which the Christian Church can reach the people in need and fulfil its mission.

Thus, the context of the article is the practical concept of Caritative Social Work being practiced in practical domains of modern social protection system. Caritative Social Work historically has developed being based in the tradition of social ministry of the Christian Church - as the practical answer of the Church to the topical needs of the outcast people in society. This caritative tradition has developed from deaconal ministry of the Early Christian Church both in Christian parishes and monasteries, beginning from the times of Christ's apostles to nowadays. For instance, in Latvia, the concept of Caritative Social Work nowadays has been developed in the officially recognized social work profession in the system of social protection of Latvia, that include professional actions for social and spiritual renewal of an individual, group and society in general (as defined in the national Law of Social Assistance and Social Services, giving a legal basis for professional activity in the national social protection system).

In order to explore the inner and outer resources that belong to individual and community for the solution of problems they are involved to solve, a researcher should pay attention to interaction between several social and religious factors when exploring local communities. One of these factors, chosen for studying in this article, is a religious capital with its inner constituting conditions in order there could take place their activation in community environment. The task here is to explore specific social and religious factors and principles of action that would provide more full understanding about the effectiveness of functioning of local religious communities and their influence to community development.

The article will end by case study analysis of two Christian ecclesial communities.

1 In Greek 'ekklèsia' - 'church, congregation'. 


\section{The devotion of the Church for the sake of people}

Speaking of the Christian Church, it has been given a potential to transform a human being in all of the levels of his or her existence. However, in the context of the article the most essential is faith-based assistance to the people, which as organized, institutional form in Western European Christian tradition is known as deacony (or the Church's social work). In it the local parish/ congregation (or church) functions as a serving community within a specific society and is answering to the needs of this particular society.

What then constitutes the devotion, orientation of the Church or the "investment" of it in one's neighbor? The social dimension of actions of a believer is defined by biblical indication (see Matthew 25: 35-36, 40) that one should act for the sake of one's neighbor - for the outcast of society, the person unprovided for, socially "the least one" (Алексий II, 2006, p. 23). Human attitude toward people who are in appalling suffering shows as a litmus the genuine attitude of a believer toward whether he or she follows the teaching of the Church or not. Respectively, what the human being is in his or her faith (taking upon oneself the cross of Christ) shows not the verbalization of his or her faith, or manifested piety, but an existential reaction to the challenge of suffering in his or her own life or life of others ${ }^{2}$. Exegesis of the Bible shows that works of mercy toward others is a process in which faith is being renewed, revived, receives its perfection (in Greek 'etheleiothe ${ }^{-3}$ ). So works of mercy are important first of all to the constitution of the Church, for ability of the Church to find itself in the position of truth, from which results the strategy for action for the Church in a local community.

In the same way it follows that the Church shows itself to the world as the Church of love (in Greek 'agape', Latin 'caritas') ${ }^{4}$, consequently based in the works of mercy toward neighbor or in 'practical works of love' (charity). Following the ideas of German Catholic theologian and psychologist Klaus Kiessling, according to the biblically-theological foundation of charity of a parish - charitable activities do not accomplish some specific God's given commandment, but is a process shaping the essence, the true identity of what is the Church. In addition, the love toward one's neighbor in unity with the love of God and as a primary act of God's love is directed really toward one's neighbor (see Matthew 22: 34-40; 25: 31-46; John 13: 14f, 34f; 15: 12,17). Living charity therefore is the criterion

$2 \quad$ One of the basic principles of "theology of the cross": "Whatever you did for one of the least of these brothers and sisters of Mine, you did for Me" (Matthew 25: 40).

3 As in Epistle of James 2: 22 "You see that his faith and his actions were working together, and his faith was made complete ('etheleiothe') by what he did".

4 According to apostle Paul, 'agape' or 'caritas' is the highest gift of the Spirit in the Church: 1 Corinthians 12: 31b-13: 13. 
of Christianness of a parish and as such cannot be delegated to anyone or anybody other. The charity of the Church thus is the task of all Christians, those in positions and simple lay people, and reaches beyond the limits of a specific parish - to all people in need (see the parable of Good Samaritan in Luke 10: 30-37, Kīslings, 2004, p. 68).

The Early Church, going through the age of persecutions and coming to the age of emperor Constantine and the Church Fathers $\left(1^{\text {st }}-4^{\text {th }}\right.$ centuries $)$, namely, in the persons of St. Gregory the Great and St. Basil the Great, strengthened the tradition of social and spiritual ministry specifically in the monasteries (beginning with $4^{\text {th }}$ century), in which the deaconal culture experienced its growth as well as obtained stable trends of development for the future ${ }^{5}$. Christianity for the first time made charity a rudimentary virtue, giving it a leading place in the moral type. It affected a completed revolution in this sphere, by regarding the poor as the special representatives of the Christian Foundator - Christ himself, and thus making the love of Christ, rather than the love of man, the principle of charity (see History of European Morals..., 1917, p. 80). Expanding the deaconal culture or culture of serving to society, the Church thus contributed and contributes to the development of a local society.

\section{The religious and social capital of the Christian Church}

In the way described above, the Christian Church develops specific culture of practical love, that gives knowledge and experience that in turn serves in order to reinforce a person's personal, ethnical, cultural or national identity as well as specific moral behavior within society. Thus the culture of love toward one's neighbor contributes to the renewal or regeneration of local societies. This level of the degree of mastery of and attachment to a religious culture, in our case to Christianity, in sociology is called a 'religious capital' (Finke, 2003, p. 3; see Bourdie, 1991; 1993; Coleman, 1990).

Religious capital primary has been understood as the contribution of the Church to local community, because involvement in religious activities is one of the kinds of social capital (being the general term), where social capital means primary the quality or relationships between individuals, social networking and formation of norms of mutual interaction and trust. That is closely linked to the so called civic virtue, where social capital is directed toward fostering of exactly this civic vir-

$5 \quad$ For the social ministry of the Early Church see the articles of Guntis Dišlers in previous editions of TILTAI: The Long-forgotten Relations between Social Practice and Religion (Vol. 63, No. 2, 2013); Three Traditions in Christian Approach to Social Issues in the Context of Social Teaching (Vol. 67, No. 2, 2014). 
tue, which most intensively finds its manifestation when it has been placed in the networking of mutual interaction of social relationships. Society that consists of many moral, but isolated individuals, not always is rich with social capital (Putnam, 2001, p. 19; see Putnam, 2003). And in the focus of all definitions of social capital there are relationships with environment and the ways, in which trustful, stable relationships among those being involved may contribute to the improvement of effectiveness of both the collective and individual activity (see Ziverte, Sociālo kontaktu tīkli kā drošumspējas faktors, p. 2).

Parallel to the scientists of social capital, such as P. Bourdie, J. Coleman, F. Fukuyama, the World Bank since 90-ties of the last century has launched a regular research program The Social Capital Initiative, focusing on the role of social capital in the development of community and national economies; these studies (see The Initiative of Defining, Monitoring and Measuring Social Capital, 1998; Grootaert, 2004) has focused on links between social capital and other phenomena of different disciplines of science. ${ }^{6}$

Having said that religious capital consists of level of the degree of mastery of and attachment to a specific religious culture, it provides also the knowledge and experience, which, in its turn, serves in order to reinforce personal, ethnical, cultural or national identity of a person as well as specific moral behavior within society, all together being connected to renewal (regeneration) of local societies (see Baker \& Skinner, 2014; Baker \& Skinner, 2005; Baker, 2012; Baker, 2016; Baker \& Smith, 2011). Finally, previous definitions allow us to define religious social capital, being the social resources available to individuals and groups through their social connections with a religious community (Maselko, 2011, p. 759-767).

\section{Examples of religious capital in Christian Churches}

Examples of the actions of the Church in local communities can be found in social activities of both the Roman Catholic, Orthodox and Protestant Churches, which reveal the social doctrine of these Churches.

6 See the first official study in Latvia of social capital: Zīverte Linda, Austers Ivars, Zilinska Dzintra. Sabiedriskie tīkli kā drošumspējas faktors [Public networks as factor of securitability]. In: Latvija. Pārskats par tautas attīstību 2002/2003: Cilvēkdrošība [Latvia. Overview on national economic development 2002/2003]/ Galv. red. [Main ed.] Māra Sīmane. Rīga: ANO Attīstības programma [UN Development Programme], 2003. - 82.-97. lpp. Available also: http://providus.lv/article_files/920/original/ UNDP2003_ful_lv.pdf?1326366357 


\section{Caritative activities of the Orthodox Church}

Speaking of activities of Orthodox Church in Latvia, the Orthodox Woman St. Trinity Monastery of St Sergius of Radonezh in capital city of Riga feeds 200 to 250 homeless people every day on their own expense, mainly from donations; as well as parishes in other cities of Latvia organizing the soup kitchens for homeless people; parish members and priests visiting people in hospitals, prisons and orphanages with moral and material assistance.

In Russia, the most prominent ecclesial service provider is The Charity Monastery of Martha \& Maria (Marfo-Mariinsky Convent in the Possession of Grand Duchess Elizabeth Feodorovna - the foundress), which provides the possibility to serve God whether as a nun - in contemplative prayer life, or as a charitable sister - in practical ministry to the people in need, not combining both, but choosing one ministry.

The Monastery has vast variety of serving the needs of local community of Moscow - it has 4 directions of social ministry: 1) Social projects; 2) Care for gravely ill people; 3) Family placement centre for children without parental care; 4) The management of the Church Association of Communities of Sisters of Mercy (see По заветам Великой княгини [Following the footsteps of Great Duchess [Elizabeth]]).

Social projects:

a) Medical center "Mercy" - free of charge medical treatment for children with cerebral stroke (since 2010 - 500 children); b) The Orthodox Orphanage of St. Elizabeth - for 20 healthy girls and girls with Down syndrome; c) St. Elizabeth's Gymnasium for children; d) Day care centre for children with disability - for children with cerebral stroke (the only one in Moscow); e) The Service of Children's Palliative Care and Hospice - for families with children with progressive, heavy incurable sicknesses; home care; and stationary; f) Mobile assistance service for patients with Amyotrophic lateral sclerosis (ALS) - medical, psychological and social assistance for quickly progressing degenerative disease of the motor neuron system ending lethally (more than 100 families); g) Assistance service for the people in hardships - 24/7 helpline, material and spiritual assistance to the poor, disabled people, pensioners, large families with children, courses for pregnant women I am not alone; help for people deprived of assistance from state or relatives; h) Volunteers Service - more than 2000 volunteers providing assistance for disabled people, large families with children at homes, transportation of sick people, care service at homes a.o.; i) Resort centre for families with disabled childrensummer camps with rehabilitation program (since 2015 - for 300 children from 150 orphanages); j) Work with substance (alcohol) abusers self-assistance groups with addicts and their family members, common prayers. 
Care for gravely ill people is organized at homes, medical institutions, places of imprisonment in all the spectrum of sicknesses, by attracting the volunteers and profiled specialists for providing specific assistance.

Family placement centre for children without parental care: a) School for Foster Parents - state-accredited 2-month training program for emerging guardians, foster parents, adopters; b) Family Assistance Service for foster parents who have asked for help - with assistance program for rehabilitation of family; c) Foster Parents $C l u b$ - regular meeting for parents raising children with lectures, training, experience sharing; assistance in crisis management leaded by professionals and priests; d) Working with kinsman (social patronage service) - psychological assistance for close relatives whose children are in orphanages with the goal to return them in their biological families; e) Masterclasses of Foster parenting - mobile workshops in state care centers for children and orphanages to increase the motivation for foster parenting; f) Working with families in crisis - to eliminate the risk of taking children out of families and crisis intervention itself.

The management of the Church Association of Communities of Sisters of Mer$c y$ - since 2010 uniting 369 sisterhoods in Russia, Belarus and Ukraine.

\section{Caritative activities of the Roman Catholic Church}

Looking to social ministry of Roman Catholic Church, it is possible to see religious capital acquired through centuries, being manifested in specific forms of ministry. For example, in Latvia alone there are functioning: a) 6 male monk orders; b) 11 female congregations (among them Mother Teresa Missionaries of Charity Sisters); c) 3 secular orders; d) 6 religious communities; e) 10 apostolic communities, movements, brotherhoods of lay people; and f) 3 philanthropical organizations (see Baznīca darbībā: Latvija, 2013). Not all activities of these organizations are primarily socially-oriented, but most of them are characterized by providing assistance to people in need. For instance, The Independent Order of Knights of the Hospital of Saint John of Jerusalem of Malta (The Order of Hospitallers) in every country, which has diplomatic relationships established or which has the Association of Maltese Order present, establishes in a country Maltese Order Association for the Assistance (MOAA), whose calling is "to stay trustful to the Church and to serve people in hardships" (Ibid., p. 16-17). MOAA organizes different events and services: camps and excursions for disabled people, young people and street children; organizes course in First Aid; organizes transportation for disabled and sick people, which in Latvia is a service in demand; organizes soup kitchens, points of distributions of clothing, is involved in integration of disabled people in society, maintains night-shelter, mother-child crisis center, leads 
workshops for disabled people and people from imprisonment; as well as boarding house for elderly people.

Most known organization of ministry in Latvia of the Roman Catholic Church is Mother Teresa Missionaries of Charity Sisters ${ }^{7}$, in which missionaries are ordained servants of the Church (clergy), goal of which is to serve without compensation from all of heart to the poorest from the poor, not considering their social status, caste, religion, race, nationality and culture. Main spheres of activity is to take care of sick and dying poor people; to gather and to teach street children; to visit and to take care of the poor, leprosy-stricken, as well as to take care of "the ones not needed to anyone, unlovable, the lonely ones". In Riga, the congregation works since 1994 and its main spheres of activity are visiting and taking care of poor families, old and lonely people at their homes or hospitals, boarding houses, orphanages, prisons; catechesis; preparing of children of poor families and homeless people for Holy Sacraments; as well as feeding, providing of medical assistance, provision of clothing to the homeless.

As a bright example of congregational activities for successful realization of religious capital serves the initiative of city of Freiburg in Germany, where Catholic and Protestant churches together with city's consultative and caritative services established cooperation in order to provide for human-becoming of people with psychic illnesses. Psychic suffering, for instance, depressions are usually hidden from view of parishes, and in the minds of people who suffer from those illnesses most often there are fears from not being understood and superstitions, which are combined with the sense of guilt and often leads to silent withdrawal of depressive people from public life, what takes away their courage even more (Kīslings, 2004, pp. 75-76).

The goal of cooperation was to find out, in what ways the parishes may become open and sensitive to people with psychic illnesses, how to gain via human care new trust, faith and hope, how to address the relatives of these people so that they also would not find themselves in psychological problems and isolation, as well as - how to involve the volunteers in care of people with psychic illnesses at their places of living?

Specific initiatives were cycles of presentations on psychic disorders and possibilities providing assistance, resulting in small groups of volunteers who get trained in basic positions of respect, sensitive assistance-providing and genuineness by providing care to these people. Additionally to these groups, there formed also

7 See Mātes Terēzes tuvākmīlestības ordeņa Žēlsirdības misionāres [Mother Teresa Missionaries of Charity Sisters] [online]. - Latvijas Konsekrētās dz̄ives institūtu priekšnieku/-ču apvienotā konference (LKDIPAK) [United Conference of Leaders of Consecrated Life Institutes of Latvia], 2015. Retrieved from: http://konsekretie.lv/ mates-terezes-tuvakmilestibas-ordena-zelsirdibas-misionares/ 
groups of relatives, where great suffering of relatives, not being aware of till now in the parish, was revealed, as well the sense of guilt, necessity for mutual assistance (becoming aware that such people are present also in other parishes, and using it as a resource), waking up the courage and sources of deaconal spirituality in order the relatives would again become able to believe vitally, to love and to hope. All that together activated many, until now passive parish members and together with others got involved in qualified Christian serving to people around (Ibid., p. 75-76).

It is clear that such a model of cooperation is not a solution to all social problems at local community, nevertheless with this work there are connected, following $\mathrm{K}$. Kiessling, the encouraging experience, - the steps in the way to reinforcement of deaconal (caritative) relevance of Christian parishes (Ibid., p. 78) and for re-socializing of different local marginalized groups by using inexhaustible sources of religious capital for renewing the personality of an individual.

Such organized local church (parish) serves as reservoir of activities of local community. It should be mentioned that the Church traditionally already from ancient times has been considered as one of the most prominent voluntary institutions, which reflects "the historical memory of local community, its sense of belonging and consciousness of identity" (Baker \& Skinner, 2014, p. 55). It should be considered that the fate of church (parish) and local community have often been and still are strongly connected.

Consequently, in the activities of groups of the Church there develop new kind of social capital, mentioned by researcher of social capital Ann Morisy. She describes the existence of brave social capital - social capital that reaches out beyond the margins of safety implied in bonding and bridging social capital to engage with the most dangerous and the most marginalized sectors of society. Her observation, relevant to this case study, is that it is often those small church groups who operate in a low-key and 'natural' way that are most effective in this work, even when they themselves are not strong or powerful in any normal criteria (Morisy, 2004, pp. 60-62).

\section{Case studies of two Christian ecclesial communities for social inclusion of the person}

In order to show the working ecclesial communities, two methodological, a little differing from each other, models of recovery and rehabilitation of addicts in ecclesial communities will be discussed as vase studies, which are based in the anthropological spiritual practice of traditional Christian Churches (Catholic and Orthodox). 
This will give also the understanding of activation of religious capital in a person's life and its influence on all levels of personality structure, as well as which elements and principles of ecclesial community can constitute the socially rehabilitating community, the goal of which is the renewal of anthropological unity of a person, not the narrow social problem.

The term 'ecclesial community' means the very Church or environment of relationships based on ecclesial foundations, in which with the specific holy means - sacraments ${ }^{8}$ - takes place the renewal of divine hierarchy of human personality - coming back of a person to its ontological normal condition - in unity with God. Entering of a person or inclusion in the organism of the Church takes place through sacrament of baptism. In the sacrament of baptism there takes place a person's reunion with God who by himself in a sacramental (e.g., mysteriously) way in a human person gives birth anew ("from above") to the life of spirit by renewing anthropological norm - person's primary, natural 'dependence' from God's existence. The sacrament of baptism is connected also with the following anthropological shifts: 1) with confession of sins (that anticipates repentance as an essential means for overcoming mental pathologies); 2) renewal of conscience ${ }^{9}$; 3) setting free of demonization, - there are formulas of exorcism in the Church ritual of baptism that foresee refusal to the evil spirit and handing over a person to God's protection.

With sacrament of baptism there starts the acquiring the mastery of and attachment to a culture of Christian spirituality and practical church life.

"The Mountain Blessings community" is ecclesial community in Latvia of spiritual and physical rehabilitation for people with addictions. The objective of community is to give possibility to a person finding his or her own way in life by using only therapy of spiritual life and work (see Kalna svêtību kopiena). The establisher of community (in 1999) and its spiritual leader is Catholic priest Andrejs Mediņš in Brukna village in Rundāle region. Structure of community is formed after type of ecclesial communities existing in Europe, in this case - based on the experience of drug addict community Senacolo (in Medjugorje, Bosnia-Herzogovina). Spiritual patroness of community is Mother Teresa of Calcutta.

8 Sacraments of the Church are specific, preserved only in the traditional Church holy actions, in which with the mediation of external material signs (water, bread, vine, a. o.) invisibly, mysteriously (resp., sacramentally) in a person takes place the transforming action of the very triune God. In sacraments there realizes real-presence of God in a person.

9 Apostle Peter characterizes sacrament as the renewal of conscience: "And this water symbolizes baptism that now saves you also - not the removal of dirt from the body but the pledge of a clear conscience towards God" (1 Peter 3: 21). 
Methods of rehabilitation are Healthy lifestyle, Work, Silence, and 'Therapy of Christ' that penetrates all processes.

At the basis of rehabilitation al methods there is a concept of man as being created by God who even in illness keeps in oneself a spiritual potential of the image of God (Imago Dei), therefore the starting point of every therapy and personality development is to cultivate and cure with the sacred means of the Church the center of personality - a spirit. Since the spiritual and physical aspect of a person is inseparably united both in health and sickness, therapy includes also physical and social practice, which can be called also the principle of ascetism (ascetism in spiritual practice of Western and Eastern Churches is understood as 'practicing' to subject life of psyche and body to the demands of spirit).

Ecclesial community through its model of rehabilitation helps normalizing inner spiritual and psychic pathologies of an addict person, puts in action human potential of freedom and facilitates social inclusion.

Relative social isolation with further perspective of social adapting. Community is located in rural region, because the goal of establishers is to separate cardinally an addict for a longer period from previous environment, until the inner structure of personality is transformed, which will determine also possibility of another lifestyle. In the beginning it is not advised to make encounters with relatives.

Conditions of life in community are very simple; in the very beginning of community they were quite rough, because residents by themselves were renovating premises meant for living. Almost all community members share that in the beginning they were unpleasantly surprised, furious, were grumbling about the lack of comfort, but after a month got used to it. Such a lifestyle where great importance is attributed to enduring discomfort and taking care of self, diminishes pathologic dependence from feelings of comfort and helps to limit pathology of sensuality. The same is achieved also by healthy food, self-cultivated products, meals before which young people were taught thanksgiving to God for daily bread in the form of prayer, as well as refusal of whole community from industrial delicacies, tonic (restorative) chemical drinks, etc. One of the rules of the community is also giving up the incitement aroused by screens and monitors, and undying zing of 'headphones' in the ears, - it is compliance to the silence, which from the beginning is simply a physical practice that cures the dispersity of consciousness, but going deeper it is learning to rule over different negative speeches and thoughts as well listening into the sacred. 
Virtue of working and divine basis of work. All members of community are involved in garden and field, construction, forest and housekeeping works. Effects of work therapy:

1) the formation of virtue of working heals the mental pathology of boredom of heart by teaching to overcome laziness, avoidance to perform duties by improving patience and diligence;

2) the community's setting to comply with the regime and its requirements normalizes involuntariness and disobedience caused by mental pathology of pride. Greatest part of community members admits that the specific regime, requirements and rules of father Medinš regarding work and life in community have aroused in them great opposition, resistance and anger, which have settled down with a time, because in daily course of life (especially in the result of spiritual lessons) their perception of things has changed. Whereas five community members have seen work therapy quite differently - as the obtaining of missing refuge, supervision and safety in their life;

3) virtue of working includes also formation of other virtues (responsibility, altruism, trust, love) - several ex-members of community point that for the first time in their life they have done something good for others. In that way the sensual, selfish standpoint in life is being suppressed as well as painful isolation (triggered by sadness and pride), instead of it developing a social capacity of a human, awareness of community with others;

4) work is a way how to develop one's own potential of spirit, to feel divine task and reason in life.

Spiritual life of 'therapy of Christ'. Specifics of spiritual life in community is defined by the situation that most members of community (drug, alcohol, gambling and other addicts) arrive here mostly as unbelievers. The community is not a narrow religious organization, which accepts only church people. 'Therapy of Christ' is not oriented towards original religious conviction of a person, but to an anthropological concept of Imago Dei in a person that anticipates the awakening of a spiritual element - a spiritual mind ('nūs' in Greek) - in a person in order, while establishing and strengthening the bound of spirit with one's Creator, a human person may experience a real anthropological transformation and setting free, disengagement from the power of pathologies.

Overcoming of anthropological pathologies (and with it also of addictions) is not possible only by the way of psychic activity or psychological self-adjustment, there is a need for synergy between the activity of a human and that of God's Holy Spirit. Only then therapy goes deep into the center of personality, about what many addicts give witness saying that it feels like "tormenting emptiness inside". This 
is anthropological judgement that shows the destruction of hierarchal structure (spirit-soul-body relation) of a person. ${ }^{10}$

That way oriented 'therapy of Christ' is being characterized by the following elements:

1. Practice of prayers - as constant spiritual 'backing' of the entire rehabilitation process, as the basis, on which all other processes are built on. Practice of prayers is realized both three times a day gathering for a prayer in a chapel for Psalm prayers and attending the church, as well the individual prayers (including prayers for others - for parents, etc.). Practicing so, people learn to understand prayer as the bond of human spirit with the Person of God. By these bonds developing, human personality is stabilizing, because when speaking to God one is forced to overcome selfishness or self-love. All community members share that from the beginning they have encountered different difficulties when overcoming obstacles set by their originally secular minds. The break in the process has appeared when following fruits have started to appear: healing tears that alleviates a heart, peace. Prayer thus regenerates a human ability to stand against influences, desires of addiction and gives birth to the power of love; prayer (a contact with God) turns human consciousness towards the Other person, there happens process of social healing ("In the beginning I prayed because there was a regime for that, because other prayed and you were praying along with others. Later I prayed to God that I long to understand why I am praying and why do I need this. Now I pray for others, so they may return from that hell, start seeking for assistance and find truth").

2. Spiritual education - getting to know the Bible, methodic of recollections, which allow understanding oneself and life in a new perspective.

3. Confession of sins - bringing of problems of soul into the light of consciousness, not muffling them with the condition of drunkenness. Confession is integral spiritual means in fight with mental pathologies - it develops the virtue of humility, recognizing one's fault, includes both asking for forgiveness and ability to forgive others. In confession, recognizing one's fault in front of God and priest, in a spiritually paradoxical way a person is set free from destructive complex of fault and from the syndrome of being a victim, which is typical for the pathology of sadness.

4. Church sacraments that forms the renewal of person's ontological bond with Creator and is unique, practically - the main resource, which inwardly sets free a person from the impact of object of addiction, and develops in a person stability of unity with God and self-determination of personality - not the psychological one, but spiritual (these are strictly separable anthropological levels in a person).

10 In details on that see: Hierotheos (Vlahos), Metropolitan of Nafpaktos. (2000) Orthodox Psychotherapy. The Science of the Fathers. Levadia, Greece: Birth of the Theotokos Monastery, $369 \mathrm{p}$. 
5. Authority of spiritual father (leader of community), which stems from the strongness of relationships with God of the very deliverer of assistance, and from the power of devotion of the very leader, because he, first of all, is a person if trust, embodying by himself all possible safety that for the sick and rejected from life person can provide embracing, inclusive, safety-giving attitude, which an addict has lacked in the life and which they are not capable of giving to anyone in the beginning. Spiritual father in some way represents accepting love of Christ, because here starts a genuine social inclusion ("My greatest experience was when I understood that Christ is real and loves me as I am. That I understood through Mediņs"'). Secondly, authority is expressed by certainty, firmness and wisdom, because strategy of rehabilitation is not oriented so that it may please human selflove (passions) of the sick person, but in order to address the hidden awareness of God or spiritual mind ('nūs') in a person. Actually, this rehabilitation is an intense spiritual fight about person's awakening for life and asks from the leader also great spiritual work with oneself, as well as incessant prayers for those he takes care of ("I have five times escaped from Brukna, but then I understood again that I myself am not capable of managing it all, and I came back. It was good that Mediňs forgave me all those five escapes, - after serious conversations he allowed me to come back. I appreciate it very highly. That was like a lesson of love, forgiveness"). Rehabilitation community of ecclesial type cannot function adequately if it has no an authorative leader who carries responsibility in front of God for the people of community. In many things leader of community defines strictly, what is to be allowed in the community and what not. It is a strategy, goal of which is the concern for the addicts and their recovery. In the process of recovery of an addict an essential role plays exactly the obedience, because it makes the egocentric clichés of consciousness to break.

6. Coinonic ${ }^{11}$ relationships of friendship. It was described already before that this kind of relationships among members of community are slowly blossoming out of practice of prayer and confession as the result of 'opening of heart'. During the course of life of community its members slowly cultivate ability to accept the other, to reckon with the other and to sacrifice oneself for the other. When problem situations arouse, relationships are to be solved by re-orienting to Christ's mind in oneself. Thus, the foundations are laid for genuine social integration.

During process of rehabilitation a spiritual work penetrates and leaves impact on any other human aspect - physical action, self-adjusting of psyche, the relationships.

11 In Greek 'koinonia' - 'community, unity' where people are conducting mutual relationships not on the basis of kinship or social psychological basis but on the basis of sacrality. 
Possible factors of risk in community: 1) in the process of rehabilitation the family members are not involved; they, when have received the 'return of the prodigal son', have not changed themselves; 2) positive effect of long isolation from surrounding social life may go hand-in-hand with additional difficulties to adapt to a new environment.

"Community of Clarity of Consciousness" 12 "Community of Clarity of Consciousness" established by the initiative of the Orthodox Church performs care of spiritual wholeness of the addicts by using different model of ecclesial methodology. This model is known in Orthodox countries of Europe (including Estonia) and Russia. Model is developed from the example known in narcology being familytype club of clarity of consciousness ${ }^{13}$, however, here it is modified into family-type ecclesial community, which exists under the auspices of parish, under the guidance of priest, and assists to addicts of drug, alcohol, nicotine, and gambling, as well as to their co-addictives and other family members (sее: «Вразуми меня, и буду жить». Беседы в общине трезвости ["Enlighten my mind, and I shall live". Conversations in the Community of Clarity of Consciousness], 2008, 209).

Concept of addiction therapy of ecclesial family-type community stems from anthropological view that structural pathologies of a human being are the causes of all addictions.

"Irresistible inclination for psychoactive substances is an integral anthropologically-spiritual ecosystemic problem" (Ibid., p. 209).

Consequently - addiction is falling in spiritual sickness of the entire personality, pathologic collapse of wholeness of personality, therefore primary there is a need not for the treatment of sickness of addiction, but recovery of personality (structural recovery of wholeness of consciousness) by fighting against mental pathologies and by renewing the capacity of sacred and social relations, and only secondary one may be treated narcologically.

The strategical line of distinguished work of Community of Clarity: "in therapy of ecclesial community there takes place problem-oriented psycho-correction" (Ibid., 209). This is a basic work in consciousness of personality - establishing a bond with sacramental life of Christ, without which there is no possibility to break the addiction. If therapy and rehabilitation is strictly rooted in this basic foundation, then the addicts in community are recommended in case of necessity go for using also a medical treatment.

12 In Rus. 'Община трезвости'.

13 In 1964 Yugoslav psychiatrist V. Udolin established the first family club of clarity of consciousness. This is unity, community organized voluntarily from families in order to discuss painful issues that have occured regarding addiction problems in families. Today such clubs are functioning in 33 countries, in Italy alone - more than 2300 . 
Methodology of community:

Recovery of people and families subjected by addictions takes place following the method of family-type coinonic formation of friendship relationships in ecclesial community, which is not a simple meeting and having conversations in group where one can alleviate his or her heart, or psychological support group, but relationships of friendship, goal of which is to lead people, every person separately and family as a whole, in a new paradigm of relationships - of love, charity, where in a person can take place healing transformations. In addition, the root or center of community is formed not by the power of human relationships, but by spiritual uniting vertical of community - the person of Christ who also forms in members of community authentic the so-called 'spirituality'. With human spirituality it is not understood some psychological inner resources of personality, but the contact with a metaphysical reality - with the Person of Triune God in the way the God's Holy Spirit enters and by cooperating with human free will (synergy) get centered in personality as its wholeness-forming entity.

This methodology includes the following methods:

1. Method of triadic dialogue that is based in the pastoral tradition of the Church and is inherited in approaches of Orthodox psychology (sее Флоренская, 2001a; 2001b). This spiritual dialogue in its structure is triune - both partners of dialogue in it prepare the space of consciousness for the presence of the person of God (the Holy Spirit), communication with Him. In the beginning the addict one (or person in remission stage) who together with some of the family members has started attending community activities (conversations) is being directed through the so-called phase of "Socratic dialogue" in a way that starts to activate abilities of a human spirit - ability of reasoning about good and evil, opening of the voice of conscience, disciplining of mind (because mind of an addict is in chaotic and 'sleeping' state), control over rough expressions of mental pathologies. This dialogic method thus directs members of community in conversation to learn, overcome the dictation of one's own ego: intolerance, using of rude words, domineering, condemning, imposing one's opinion, inattentiveness and not listening to what is said by the other, interruption of the other speaker, raising of voice until level of yelling, aggressiveness, falseness, fear, distrust, and other qualities. The fullness (i.e., a shift from Socratic to triadic conversation) this method may achieve because at the same time the ecosystemic approach is realized.

2. Ecosystemic method ${ }^{14}$ anticipates that a person during process of rehabilitation at the same time strike roots in inclusive systems or 'returns home' (Gr. 'oikos'), primary - in the Church (that theologically correct should be understo-

14 'eko' - from Greek 'oikos' - 'home, roof'. 
od as sacramental God-humane organism of Christ), and through it - in family, and only afterwards in the other social structures, to which a person wants belonging to. Inclusion in Church Slavonic is described with hard to translate term 'воиерковление' that literally can be uttered with neologism 'striking roots in church', however, by design there is meant re-orientation of all the aspects of human life (the inner processes of soul, that of physical, everyday, matrimonial, working life, raising of children, etc.) in accordance with the sacred determinations. There is happening the sacralization of life, and thus in society there are renewed an authentic 'spiritual culture' and embodied a lot mentioned 'spiritual values', which are in essence the terms that acquire their content only being based in the sacraments of the Church. Therefore the term 'воиерковление' can be used as reintegration of human individual and social life in the Church. Given that, do not allow developing a dualism between human religious and sacred life.

Ecosystemic reintegration is being realized not only within the inner communication of community by once a week attending meetings where people talk through and jointly seek for solution to problems of people, but parallel also through the following processes:

- catharsic (cleansing, purifying) ${ }^{15}$ impact of confession (sacrament of confession anticipates also that a human being in the person of priest inherits a spiritual father for oneself and counselor);

- entering in the time-space of the Liturgy;

- observing of fasting in accordance to a liturgical year and, of course, a constant fight about withdrawal from substances causing addiction;

- practicing of individual prayer order established by the Church;

- the Church sacraments;

- community pilgrimages;

- mutual practical assistance of families in community and other deeds of mercy,

- "the promise of abstinence".

3. Diagnosing of mental pathologies and fight with mental pathologies is the basic method of personality recovery and rehabilitation that is being implemented in integrative unity with the methods mentioned above.

4. Pastora ${ }^{16}$ method or method of spiritual leadership, which is executed by a clergyman, the leader of family community. Pastoral activity (both in individual

15 In Greek 'kataros' - 'pure'; 'katarsis' - 'purification'.

16 In Latin 'pastor' - 'shepherd'. In the Church it is 'shepherd of souls' - a priest who at the basis of his ministry has the archetype of the divine Shepherd Christ - the Good Shepherd. 
approach and in community conversations) is being practiced by following the method of triadic dialogue - priest is a partner of conversation and dialogically refers to the human problems and questions, but at the same time by subjecting to the guidance of the Holy Spirit he directs therapeutic process by the way of ecclesial methodology, does not allowing it to become secularized.

The statistics on these processes are also available - the summarized data ${ }^{17}$ of Community of Clarity under the auspices of St. Nicholas Orthodox Church (in outskirts of Moscow) about the period of 1999-2008 are following: in total 184 people have participated in the program, from which 80 have been family members of the addicts. Consultations and first meeting of acquaintance have been attended by more 204 people who had no more attending repeatedly. From 104 addicts being in community 55 have been people, which have participated in community activities regularly (at least once a week) and longer than year and a half, at the same time becoming the members of the Church. From this group of regular members - in total 42 people $(77 \%$ ) have recovered and been set free from their addictions (alcohol and drug abuse).

\section{Conclusions}

Methodological success of ecclesial type of rehabilitation communities: 1) addiction is being treated in its anthropological or spiritual cause - by renewing in the mental structure of a person virtues and ontological basic norm - a freedom of spirit; 2) people who have recovered are practically included in long-term inclusive and supportive structures: in the community, the Church and, as being shown by the experience of the second community, also in family, which together with the addict has went through the healing program for overcoming co-addiction and secular lifestyle. These support structures is the foundation where a person has possibility to start overcoming social isolation, fully socialize, and integrate in society (to work, learn, establish a family, etc.) thus facilitating the social inclusion of a person.

In "The Mountain Blessings community" methods of rehabilitation are healthy lifestyle, work, silence, and 'Therapy of Christ' that penetrates all processes. Thus Catholic ecclesial community through its model of rehabilitation includes: relative social isolation with further perspective of social adapting; ascetic conditions of life; virtue of working and divine basis of work, as well as 'Therapy of Christ',

17 Sее: «Вразуми меня, и буду жить». Беседы в общине трезвости [“Enlighten my mind, and I shall live". Conversations in the Community of Clarity of Consciousness] (2008). Москва: Дом Милосердия [House of Mercy]. 
including: 1) practice of prayers; 2) spiritual education; 3) confession of sins; 4) Church sacraments; 5) authority of spiritual father (leader of community); 6) coinonic relationships of friendship.

In its turn, the Orthodox "Community of Clarity of Consciousness" shows that methodology of community is family-type coinonic formation of friendship relationships and includes: 1) method of triadic dialogue; 2) ecosystemic method; 3) diagnosing of mental pathologies and fight with mental pathologies as the basic method of personality recovery and rehabilitation; and 4) pastoral method or method of spiritual leadership. This approach of ecclesial community shows that primary there is a need not for the treatment of sickness of addiction, but recovery of personality - structural recovery of wholeness of consciousness, by renewing the capacity of sacred and social relations, and only secondary a person is treated narcologically. This is the principle of anthropological unity that differs ecclesial communities from secular community practices.

Approach of ecclesial communities shows the mechanisms of activation of religious capital in a person's life and its influence on all levels of personality structure. As well in conclusions one can observe the elements and principles of ecclesial community that can constitute the community of social rehabilitation, the goal of which is the renewal of anthropological unity of a person, not the narrow social or medical problem primary. In conclusion, in this approach of importance becomes: anthropological focus of therapy - centered for transformation of the entire personality; work with a person's mental pathologies; orientation toward Church sacraments; the authority of leader of ecclesial community; and shared life with the people in need.

In concluding, the goal of such contextual analysis of community is to come to radical, effective models of social practice, by applying an adequate social analysis un interaction of the factors mentioned in the article in the environment where diminishing of social exclusion may take place. With facilitation of these factors and principles it is possible to secure the sustainable development of community, where local society transforms into community, whose members develop competence in solving those problems that directly influence their lives.

In that way, the principle of co-activity of individuals of community is fostered, thus facilitating social inclusion, development of resources and social skills of individuals, as well as forming of civic local environment, and giving to a community the sense of identity and so needed quality of sustainability - a competence and stability in solving of social and spiritual problems being commonly aware of. 


\section{Bibliography}

The Holy Bible: New International Version. (1993). Grand Rapids, Michigan: Zondervan.

Baker, Ch., Skinner, H. (2014). Faith in Action: The dynamic connection between religious and spiritual capital. Manchester: William Temple Foundation.

Baker, Ch., Skinner, H. (2014). Regenerating Communities: A theological and strategic critique: End of year two report: Telling the stories: How churches are contributing to social capital. Manchester: William Temple Foundation. Available at: http://williamtemplefoundation.org.uk/wp-content/uploads/2014/03/Telling-theStories-Baker-Skinner.pdf

Baker, Ch. (2012). Spiritual Capital and Economies of Grace - Refining the Relationship between Religion and the Welfare State. Social Policy and Society, Vol. 11 (4), p. 565-576.

Baker, Ch. (2016). Sustainable governance in a postsecular public sphere: re-assessing the role of religion as a cosmopolitan policy actor in a diverse and globalised age. Sustainable Development, Vol. 24, p. 190-198.

Baker, C., Smith, G. (2011). Spiritual, religious and social capital - exploring their dimensions and their relationship with faith-based motivation and participation in UK civil society. Summary working paper Manchester: William Temple Foundation (Based on a paper presented at the BSA Sociology of Religion Group Conference, Edinburgh April 2010).

Baznīca darbībā: Latvija [The [Roman Catholic] Church in Latvia]/ Mat. apkop. [Comp. by] Agnese Kozlovska. (2013). Rīga: Latvijas Romas katoḷu Baznīcas informācijas centrs [Riga: Information Centre of Roman Catholic Church in Latvia].

Bourdieu, P. (1991). The forms of capital. In J. Richardson (ed.). Handbook of theory and research for the sociology of education. New York: Greenwood, p. 241-258.

Bourdieu, P. (1993). Sociology in Question. Sage: London.

Coleman, J. S. (1990). Foundations of social theory. Cambridge MA: Harvard University Press.

Dišlers, G. (2013). The Long-forgotten Relations between Social Practice and Religion. Tiltai [Bridges], Vol. 63, No. 2, p. 13-30.

Dišlers, G. (2014). Three Traditions in Christian Approach to Social Issues in the Context of Social Teaching. Tiltai [Bridges], Vol. 67, No. 2, p. 137-150.

Finke, R. (2003). Spiritual Capital: Definitions, Applications, and New Frontiers. Retrieved from: http:// metanexus.org/archive/spiritualcapitalresearchprogram/pdf/finke.pdf

Grootaert, Ch., Narayan, D., Nyhan-Jones, V., Woolcock, M. (2004). Measuring Social Capital: An integrated questionnaire. World Bank Working Paper No. 18. Washinghton, D.C.: The World Bank.

Hierotheos (Vlahos), Metropolitan of Nafpaktos. (2000). Orthodox Psychotherapy. The Science of the Fathers. Levadia, Greece: Birth of the Theotokos Monastery.

History of European Morals from Augustus to Charlemagne. (1917). W. E. H. Lecky, Vol. 2. $3^{\text {rd }}$ ed. New York: D. Appleton.

Kalna svētību kopiena [The Mountain Blessings ' Community] [online]. Available at: http://www.brukna.lv/

Kīslings, K. (2004). Praktiski projekti diakoniskas kultūras iedzīvināšanai. Vai atstāt Baznīcu ciemā? Pilsētas sociālās pastorālaprūpes aizsākumi [Kiessling, Klaus. Practical projects for implementing a deaconal culture. Should the Church be left in the village? The origins of social pastoral care of cities]. Jūs sveicina mīlestība: Raksti par diakonisku kultūru ["Love greets you...": Articles on deaconal culture]. Rīga: Latvijas Kristīgā akadēmija, apgāds Izglītība [Latvian Christian Academy], p. 58-80.

Maselko, J., Hughes, C., Cheney, R. C. (2011). Religious social capital: Its measurement and utility in the study of the social determinants of health. Social Science \& medicine, Vol. 73, Issue 5, p. 759-767. Available also: https://www.ncbi.nlm.nih.gov/pmc/articles/PMC4169277/\#R9

Mātes Terēzes tuvākmīlestības ordeṇa Žēlsirdības misionāres [Mother Teresa Missionaries of Charity Sisters] (2015). [Online]. Latvijas Konsekrētās dzīves institūtu priekšnieku/-ču apvienotā konference (LKDIPAK) [United Conference of Leaders of Consecrated Life Institutes of Latvia]. Available also: http://konsekretie. lv/mates-terezes-tuvakmilestibas-ordena-zelsirdibas-misionares/

Morisy, A. (2004). Journeying Out: A New Approach to Christian Mission. London: Morehouse.

Putnam, R. D. (2001). Bowling Alone: The collapse and revival of American community. New York, NY: Simon \& Shuster, Inc.

Putnam, R. D., Feldstein, L. M., Cohen, D. (2003). Better Together: Restoring the American community. New York, NY: Simon \& Shuster, Inc. 


\section{THE CONTRIBUTION OF ECCLESIAL COMMUNITIES TO THE DEVELOPMENT OF...}

The Initiative of Defining, Monitoring and Measuring Social Capital. Overview and Program Description. (1998). Social Capital Initiative Working Paper No. 1.Washington, D.C.: World Bank.

Zīverte, L., Austers, I., Zilinska, D. (2003). Sabiedriskie tīkli kā drošumspējas faktors [Public networks as factor of securitability]. Latvija. Pārskats par tautas attīstību 2002/2003: Cilvēkdrošība [Latvia. Overview on national economic development 2002/2003]. Rīga: ANO Attīstības programma [UN Development Programme]. Available also: http://providus.lv/article_files/920/original/UNDP2003_ful_lv.pdf?1326366357

Zīverte, L., Austers, I., Zilinska, D. Sociālo kontaktu tīkli kā drošumspējas faktors [Melnraksts krājumam: Latvija. Pārskats par tautas attīstību 2002/2003] [Networks of Social Contacts as Factor of Securitability (Draft for edition: Latvia. Overview on national economic development 2002/2003, UN Development Programme)].

Алексий II, Святейший Патриарх Московский и всея Руси [Alexiy II, His Holiness Patriarch of Moscow and all Russia]. (2006). «Остерегайтесь производящих разделения и соблазны...»: О социальном служении [“Be aware of those who produce splitting and temptations...": On social ministry]. Искушения наших дней. В защиту иерковного единства [The temptations of our days. In defence of the unity of the Church]. Москва: Даниловский благовестник [Moscow: The Messenger of Monastery of St. Daniel of Moscow], p. 5-30, 23.

«Вразуми меня, и буду жить». Беседы в общине трезвости ["Enlighten my mind, and I shall live". Conversations in the Community of Clarity of Consciousness] (2008). Москва: Дом Милосердия [Ноuse of Mercy].

По заветам Великой княгини [Following the footsteps of Great Duchess [Elizabeth]] [online]. MарфоМариинская Обитель милосердия [Marfo-Mariinsky Convent of Charity], 2014-2017. Available at: http://www.mmom.ru/mmom/

Флоренская, Т. А. (2001a). Диалог в практической психологии. Наука о душе [Dialogue in practical psychology. Science of the souls]. Москва: Владос.

Флоренская, Т. А. (2001b). Диалоги о воспитании и здоровье: духовно ориентированная психотерапия [Dialogues on upbringing and health: spiritually-oriented psychotherapy]. Москва: Школьная пресса. 
